\title{
The Effect of Zakat, Poverty, Unemployment, and Per Capita Income on HDI Through Economic Growth As Intervening Variables in Central Java Period 2017-2020
}

\author{
Erin Yulfitasari ${ }^{1}$, and Anton Bawono ${ }^{1 *}$ \\ ${ }^{1}$ Faculty of Islamic Economics and Business, IAIN Salatiga, Indonesia
}

\begin{abstract}
The purpose of this study was to determine the effect of zakat, poverty, unemployment, and income per capita on the human development index in Central Java with economic growth as an intervening variable. This research is a quantitative research with secondary data taken from the Central Java Baznas and the BPS website. The data used is panel data, which is a combination of time series data from 2017-2020 and cross section data of 35 districts/cities. The population of this study is in districts/cities in Central Java with saturated sampling. The analysis tool uses eviews 9.0 with regression analysis selected fixed effect model. The results showed that zakat and poverty had a significant effect on HDI, while unemployment and income per capita had no significant effect on HDI. Then zakat and poverty have a significant effect on economic growth, while unemployment and per capita income do not have a significant effect on economic growth. But economic growth has a significant effect on HDI. Then, simultaneously the variables of zakat, poverty, unemployment, and income per capita have no effect on HDI with economic growth as moderating.
\end{abstract}

Keywords: zakat, poverty, unemployment, per capita income, economic growth

\section{Introduction}

Development describes the means used to achieve regional goals. The goal of the Indonesian people is to advance the general welfare and educate the nation's life in the introduction to the 1945 Constitution. In the realization of development, high economic progress is the main goal of developing countries because economic progress is very strongly related to the increase in goods and services obtained by the community, finally the peace of the population will increases with the increase in goods and services obtained. Based on the quality of life of each country, the development paradigm that is currently developing is economic growth as measured by human development. The human development index is a benchmark for measuring the standard of living of humans (Murniati \& Beik, 2012).

* Corresponding author: antonbawono@iainsalatiga.ac.id 


\section{$A I C \overline{I E B}$ Annual International Conference \\ on Islamic Economics and Business, 2021}

The human development index forms economic parameters that are used to measure the level of community welfare in an area, which is measured using elements of education, health and the economy. The human development index is measured according to data that can realize the standard of human life. First, using life expectancy to calculate the achievements of public health development. Second, to describe the range of development in a socioeconomic field, data on the purchasing power of people's basic needs are used. Third, the component to describe the range of development in education, namely information on literacy levels and years of schooling in an area. The closer to the nominal 100, so the HDI of a region also increases. On the other hand, if the human development index of an area leads to nominal one, the range of human development in that area will be less good (Riadi, 2020).

In the following, the development of the human development index in Indonesia and Central Java for the 2017-2020 period is presented.

Table 1.1 Indonesia's Human Development Index (HDI) by Component, 2017-2020

\begin{tabular}{|l|c|c|c|c|c|}
\hline \multicolumn{1}{|c|}{ Component } & Unit & 2017 & 2018 & 2019 & 2020 \\
\hline $\begin{array}{l}\text { Expected Age } \\
\text { at Birth } \\
\text { (UHH) }\end{array}$ & Period & 71,06 & 71,20 & 71,34 & 71,47 \\
\hline $\begin{array}{l}\text { Old School } \\
\text { Expectations } \\
\text { (HLS) }\end{array}$ & Period & 12,85 & 12,91 & 12,95 & 12,98 \\
\hline $\begin{array}{l}\text { Average } \\
\text { Length of } \\
\text { School (RLS) }\end{array}$ & Period & 8,10 & 8,17 & 8,34 & 8,48 \\
\hline $\begin{array}{l}\text { Directed } \\
\text { Expenditure } \\
\text { per Capita } \\
\text { (PPP) }\end{array}$ & Rp000 & 10,664 & 11,059 & 11,299 & 11,013 \\
\hline \multicolumn{2}{|l|}{ HDI } & $\mathbf{7 0 , 8 1}$ & $\mathbf{7 1 , 3 9}$ & $\mathbf{7 1 , 9 2}$ & $\mathbf{7 1 , 9 4}$ \\
\hline
\end{tabular}

Source: BPS data processed, 2021

According to data from the Central Statistics Agency (BPS), human development in Indonesia continues to progress. In 2020, Indonesia's Human Development Index (HDI) reached 71.94. Compared to 2019, this figure has increased by 0.02 points or $0.03 \%$. The life expectancy of babies born in 2020 is 71.47 years, 0.13 years longer than babies born the previous year. In 2019, seven year olds are expected to enjoy 12.98 years of education (almost the same as the time required to complete Diploma I), an increase of 0.03 years compared to the previous year which was 12.95 .

The average population aged over 25 years has been in education for 8.48 years (almost equivalent to completing Level IX education), an increase of 0.14 years compared to 2019 which was 8.34. However, there was a slowdown in HDI growth in 2020 with per capita expenditure per year (PPP) of 11.30 million rupiah in 2019 dropping to 11.01 million rupiah in 2020. (BPS, 2020).

Furthermore, human development in Central Java has progressed in 2020 as seen through the increase in the Human Development Index (IPM). Despite being affected by the Covid19 Pandemic, Central Java's HDI increased by 0.14 points in 2020. Seen in 2019 it was 71.73 points to 71.87 points in 2020. Since 2017 the state of human development in Central Java has reached a high category (HDI> 70), and between 2010 and 2016 it was in the moderate category $(60<\mathrm{HDI}<70)$. 


\section{$A I C \overline{C E B}$ Annual International Conference \\ on Islamic Economics and Business, 2021}

Table 1.2 Central Java Human Development Index (HDI) by Component, 2017-2020

\begin{tabular}{|c|c|c|c|c|c|}
\hline Component & Unit & 2017 & 2018 & 2019 & 2020 \\
\hline (1) & (2) & (3) & (4) & (5) & (6) \\
\hline $\begin{array}{l}\text { Expected Age } \\
\text { at Birth } \\
\text { (UHH) }\end{array}$ & Period & 74,08 & 74,18 & 74,23 & 74,37 \\
\hline $\begin{array}{l}\text { Old School } \\
\text { Expectations } \\
\text { (HLS) }\end{array}$ & Period & 12,57 & 12,63 & 12,68 & 12,70 \\
\hline $\begin{array}{l}\text { Average } \\
\text { Length of } \\
\text { School (RLS) }\end{array}$ & Period & 7,27 & 7,35 & 7,53 & 7,69 \\
\hline $\begin{array}{l}\text { Directed } \\
\text { Expenditure } \\
\text { per Capita } \\
\text { (PPP) }\end{array}$ & Rp000 & 10,377 & 10,777 & 11,102 & 10,930 \\
\hline \multicolumn{2}{|c|}{ HDI } & 70,52 & 71,12 & $\mathbf{7 1 , 7 3}$ & 71,87 \\
\hline
\end{tabular}

Source: BPS data processed, 202

During 2019-2020, the constituent elements of HDI have increased. It can be seen that newborns in Central Java have a life span of up to 74.37 years, which is 0.14 years longer in 2020. Children aged 7 years have the opportunity to go to school for 12.70 years or an increase of 0.02 years. People aged 25 years and over have an average of 7.69 years of education (junior high school level 1). However, the people's per capita expenditure as determined by PPP (Purchasing Power Parity) fell to 10.93 million rupiah, which is Rp. 172,000 in 2020 . Therefore, with this growth, people's welfare will be increasingly realized and human development will progress (BPS, 2020).

Furthermore, the differences in the results of several studies, including research (Murniati \& Beik, 2012) explained that zakat has a positive effect on the human development index. (Syukri \& Gunawan, 2020) it is stated that zakat with life expectancy and education index has no effect, but zakat has a significant effect on purchasing power index. Then the study (Ningrum et al., 2020) concluded that poverty and unemployment had a significant effect on the human development index.

Next research by Sasana (2012) states that per capita income and human development index do not have a relevant effect. This is different from what was studied (Juliarini, 2019) which concluded that there was a strong positive relationship between regional income and HDI. Then research Suparyati (2014) states that for a group of countries with high HDI only income per capita has an effect on the human development index. Meanwhile, countries with low HDI per capita income have no effect on HDI.

Based on previous research which showed irrelevant results, further research needs to be done. So that the author can review the existence of the theory that has been strengthened. The difference between this research and previous research is that it uses three variables as research subjects, panel data and economic growth variables are used as moderators.

Based on the background and differentiating research results above, the author will carry out further research entitled "The Effect of Zakat, Poverty, Unemployment, and Per capita Income on HDI through Economic Growth as an Intervening Variable in Central Java for the 2017-2020 Period".

\section{Method}

The type of research used in this research is quantitative research. This study uses combined data, namely time series data from 2017-2020 and a cross section consisting of 29 districts 


\section{$A \mathrm{C} \overline{I E B}$ Annual International Conference \\ on Islamic Economics and Business, 2021}

and 6 cities in Central Java. The sample in this study uses a saturated sample, that is, the entire population is part of the sample. The data sources used are secondary data in the form of zakat, poverty, unemployment, income per capita, HDI, and economic growth through government institutions such as BAZNAS and the Central Statistics Agency (BPS). This study analyzed the data using multiple analysis techniques with mediating variables using path analysis which was processed using software version 9.0 eviews.

\section{Result and Discussion}

\subsection{Stationarity Test}

This study used a stationarity test using a unit root test at the level level. Stationary data if the probability value $<0.05$.

Furthermore, the stationarity test is presented on each of the following variables :

Table 3.1 Stationarity Experiment

\begin{tabular}{|c|l|c|c|}
\hline No & \multicolumn{1}{|c|}{ Variable } & Probability unit root & Results \\
\hline 1 & HDI & 0.0000 & Level stationarity \\
\hline 2 & Zakat & 0.0000 & Level stationarity \\
\hline 3 & Poverty & 0.0000 & Level stationarity \\
\hline 4 & Unemployment & 0.0001 & Level stationarity \\
\hline 5 & Income per capita & 0.0001 & Level stationarity \\
\hline 6 & Economic growth & 0.0000 & Level stationarity \\
\hline
\end{tabular}

Based on the table above, it can be seen that the data is less than 0.05 which shows that all variables are stationary. This means that the data is suitable for the next test.

\subsection{Test Statistics}

After the regression analysis was carried out, the conjecture suitability test was carried out and the results were explained and presented below.

Table 3.2 Statistical Test Experiments

\begin{tabular}{crrrr}
\hline \hline Variable & Coefficient & Std. Error & t-Statistic & Prob. \\
\hline \hline C & -8019.896 & 6914.587 & -1.159852 & 0.2489 \\
X1ZAKAT & $2.44 \mathrm{E}-09$ & $5.96 \mathrm{E}-08$ & 0.040908 & 0.9675 \\
X2KEMISKINAN & -1284.105 & 102.6113 & -12.51427 & 0.0000 \\
X3PENGANGGURAN & 0.191938 & 0.426865 & 0.449646 & 0.6539 \\
X4 & 0.012721 & 0.007045 & 1.805528 & 0.0740 \\
ZPERTUMBUHAN_EKONO & 1.957765 & 0.400159 & 4.892471 & 0.0000 \\
MI & Effects Specification & \\
\hline \hline
\end{tabular}

Cross-section fixed (dummy variables)

R-squared

Adjusted R-squared
0.870712 Mean dependent var

0.820289 S.D. dependent var
6093.757

2172.071 


\section{$A I C \overline{I E B}$ Annual International Conference \\ on Islamic Economics and Business, 2021}

\begin{tabular}{lrll} 
S.E. of regression & 920.7912 & Akaike info criterion & 16.72330 \\
Sum squared resid & 84785645 & Schwarz criterion & 17.56377 \\
Log likelihood & -1130.631 & Hannan-Quinn criter. & 17.06484 \\
F-statistic & 17.26833 & Durbin-Watson stat & 2.518325 \\
Prob(F-statistic) & 0.000000 & & \\
\hline \hline
\end{tabular}

Source: secondary data processed, 2021

Based on table 3.2, the following tests were carried out on the significance shaded by the following test:

\section{a. T test (individual test)}

1. The constant shows the coefficient value of $-8019,896$ which means that if the independent variable is equal to (0) then the human development index is 8019,896 with the assumption that the other variables are stable.

2. Variable X1 (zakat) is stated with a coefficient value of $2.44 \mathrm{E}-09$ and the probability value is $0.9675>0.05$. Then zakat is declared to have a positive but irrelevant effect on the human development index.

3. Variable $\mathrm{X} 2$ (poverty) shows a coefficient value of -1284.105 with a probability value of $0.0000<0.05$. Then zakat is concluded to have a negative and relevant effect on HDI.

4. Variable X3 (unemployment) is indicated by the coefficient value of 0.191938 and the probability value of $0.6539>0.05$. Then unemployment is stated to have a positive but irrelevant effect on HDI.

5. Variable X4 (per capita income) shows the coefficient value is 0.012721 and the probability value is $0.0740>0.05$. Then per capita income has a positive but irrelevant effect on HDI.

6. Variable $\mathrm{Z}$ (economic growth) shows the coefficient value of 1.957765 and the probability value is $0.0000<0.05$. Then economic growth has a positive and relevant effect on HDI.

\section{b. F test (simultaneous)}

Based on table 3.2 above, it can be seen that the coefficient value is 17.26833 and the probability value is $0.000000<0.05$, which means that together the independent variables have a positive and relevant effect on the human development index.

\section{c. R2 Test (Coefficient of Determination)}

Based on table 3.2 which is shown above, the coefficient of determination of the regression model between the dependent independent variable is adjusted $\mathrm{R}$ square of 0.820289 , which means that the independent variable affects $82.0289 \%$. While the rest are influenced by other variables.

To understand the effect of mediation, then proceed with the following Sobel test:

1. Zakat variable (X1)

$$
\begin{aligned}
Z & =\frac{\mathrm{ab}}{\sqrt{{b^{2} \mathrm{SE}_{\mathrm{a}}^{2}}^{2}+\sqrt{\mathrm{a}^{2} \mathrm{SEb}^{2}}}} \\
& =\frac{(0.02)(4.21)}{\sqrt{\left(4.21^{2}\right)\left(0.003^{2}\right)}+\sqrt{\left(0.02^{2}\right)\left(1.56^{2}\right)}} \\
& =\frac{0.0842}{\sqrt{(17.7241)(0.000009)}+\sqrt{(0.0004)(2.4336)}} \\
& =\frac{0.0842}{\sqrt{0.0001595169}+\sqrt{0.00097344}} \\
& =\frac{0.0842}{\sqrt{0.0011329569}}
\end{aligned}
$$




\section{A I $\overline{I E B}$ Annual International Conference \\ on Islamic Economics and Business, 2021}

$$
=\frac{0.0842}{0.0336}=2.505
$$

From the results above, the z-value is 2.505 , which means $>1.96$ with a significance level of 5\% and proves that economic growth can mediate the relationship between the influence of zakat on HDI.

2. Poverty variable $(\mathrm{X} 2)$

$$
\begin{aligned}
Z & =\frac{\mathrm{ab}}{\sqrt{{b^{2} \mathrm{SE}_{\mathrm{a}}^{2}}^{2}+\sqrt{\mathrm{a}^{2} \mathrm{SEb}^{2}}}} \\
& =\frac{(-0.119)(4.21)}{\sqrt{\left(4.21^{2}\right)\left(0.022^{2}\right)}+\sqrt{\left(-0.119^{2}\right)\left(1.56^{2}\right)}} \\
& =\frac{-0.50099}{\sqrt{(17.7241)(0.000484)}+\sqrt{(0.014161)(2.4336)}} \\
& =\frac{-0.50099}{\sqrt{0.0085784644}+\sqrt{0.0344622096}} \\
& =\frac{-0.50099}{\sqrt{0.043040674}} \\
& =\frac{-0.50099}{0.20746}=-2.414
\end{aligned}
$$

From the results above, the $\mathrm{z}$ value is $-2,414$ which means less than 1.96 with a significance level of $5 \%$ and proves that economic growth is not able to mediate the relationship between poverty and the human development index.

3. Unemployment variable (X3)

$$
\begin{aligned}
Z & =\frac{\mathrm{ab}}{\sqrt{{b^{2} \mathrm{SE}_{\mathrm{a}}^{2}}^{2}}+\sqrt{\mathrm{a}^{2} \mathrm{SEb}^{2}}} \\
& =\frac{(-0.018)(4.21)}{\sqrt{\left(4.21^{2}\right)\left(0.049^{2}\right)}+\sqrt{\left(-0.018^{2}\right)\left(1.56^{2}\right)}} \\
& =\frac{-0.07578}{\sqrt{(17.7241)(0.002401)}+\sqrt{(0.000324)(2.4336)}} \\
& =\frac{-0.07578}{\sqrt{0.0425555641}+\sqrt{0.0007884864}} \\
& =\frac{-0.07578}{\sqrt{0.0433440505}} \\
& =\frac{-0.07578}{0.2081}=-0.3641
\end{aligned}
$$

From the results above, the $\mathrm{z}$ value is -0.3641 , which means less than 1.96 with a significance level of $5 \%$ and proves that economic growth is not able to mediate the relationship between the influence of unemployment on the human development index.

4. Income per capita variable (X4)

$$
\begin{aligned}
Z & =\frac{\mathrm{ab}}{\sqrt{b^{2} \mathrm{SE}_{\mathrm{a}}^{2}}+\sqrt{\mathrm{a}^{2} \mathrm{SEb}^{2}}} \\
& =\frac{(0.0021)(4.21)}{\sqrt{\left(4.21^{2}\right)\left(0.0022^{2}\right)}+\sqrt{\left(0.0021^{2}\right)\left(1.56^{2}\right)}} \\
& =\frac{0.008841}{\sqrt{(17.7241)(0.00000484)}+\sqrt{(0.00000441)(2.4336)}} \\
& =\frac{0.008841}{\sqrt{0.000085784644}+\sqrt{0.000010732176}} \\
& =\frac{0.008841}{\sqrt{0.00009651682}} \\
& =\frac{0.008841}{0.0098}=0.902
\end{aligned}
$$




\section{$A \mathrm{C} \overline{I E B}$ Annual International Conference \\ on Islamic Economics and Business, 2021}

From the results above, the $\mathrm{z}$ value is 0.902 , which means less than 1.96 with a significance level of 5\% and proves that economic growth cannot mediate the relationship between the influence of income per capita on HDI.

Based on the results of the Sobel test above, the t statistic value ( $t$ count) of the following mediation effect is calculated:

$$
\text { 1. } \begin{aligned}
\mathrm{t} 1 & =\frac{\mathrm{p} 5 \cdot \mathrm{p} 9}{\mathrm{z}} \\
& =\frac{0.0902788179}{2.505} \\
& =0.036 \\
\text { 2. } \mathrm{t} 2 & =\frac{\mathrm{p} 6 . \mathrm{p} 9}{\mathrm{z}} \\
& =\frac{-0.501708047}{-2.414} \\
& =0.207
\end{aligned}
$$

$$
\text { 3. } \begin{aligned}
\mathrm{t} 3 & =\frac{\mathrm{p} 7 . \mathrm{p} 9}{\mathrm{z}} \\
& =\frac{-0.0790287012}{-0.3641} \\
& =0.217
\end{aligned}
$$

$$
\text { 4. } \begin{aligned}
\mathrm{t} 4 & =\frac{\mathrm{p} 8 . \mathrm{p} 9}{\mathrm{z}} \\
& =\frac{0.00893862188}{0.902} \\
& =0.009
\end{aligned}
$$

Based on the calculations above, the following is described:

1. The position of economic growth as a mediation between zakat and the human development index, can be calculated from the value of $t$ count $0.036<t$ table $(\mathrm{N}$ 140) with a probability of $5 \%$ worth 1.65857 . Then it means that the mediation coefficient is irrelevant and means that economic growth cannot be a link between zakat on HDI. This result states that zakat has no effect on HDI through economic growth.

2. The position of economic growth to mediate poverty and human development index, can be calculated from the value of $t$ count $0.207<t$ table $(\mathrm{N} 140)$ with a probability of $5 \%$ worth 1.65857 . Then it means that the mediation coefficient is irrelevant and means that economic growth cannot be a link between poverty in the human development index. This result states that poverty has no effect on the human development index through economic growth.

3. The position of economic growth as a mediation between unemployment and the human development index, can be calculated from the value of $t$ count $0.217<t$ table $(\mathrm{N} 140)$ with a probability of $5 \%$, which is 1.65857 . Then it means that the mediation coefficient is irrelevant and means that economic growth cannot mediate unemployment and the human development index. This result states that unemployment has no effect on the human development index through economic growth.

4. The position of economic growth as a mediation between per capita income and the human development index can be calculated from the $t$ count $0.009<\mathrm{t}$ table $(\mathrm{N} 140)$ with a probability of $5 \%$, which is 1.65857 . Then it means that the mediation coefficient is irrelevant and means that economic growth cannot mediate on per capita income and the human development index. This result states that income per capita has no effect on HDI through economic growth.

\section{Discussion and Conclusion}

This study intends to detect the effect of zakat, poverty, unemployment, and per capita income on HDI by means of economic growth. A review of each variable is described below: 


\section{$A \mathrm{C} \overline{I E B}$ Annual International Conference \\ on Islamic Economics and Business, 2021}

\section{The effect of zakat on HDI}

Based on the results of multiple linear regression on the regression coefficients obtained a positive value of 0.148129 and prob. $0.0192<0.05$. Then it is concluded that the zakat variable has a positive and relevant effect on HDI, (H1 accepted).

This explains the increasing distribution of funds zakat, the standard of human life will increase. When funds zakat is distributed properly and evenly, then someone in meet the need to be fulfilled and the potential to pay zakat can also be realized. With that, then social welfare also increases.

2. Effect of poverty on HDI

Based on the results of multiple linear regression on the regression coefficient, it is obtained a negative value of -4.505573 and prob. $0.0000<0.05$. Then it is stated that the poverty variable has a negative and relevant effect on HDI. (H2 accepted).

Poverty which then results in a gap human development and then the government does not achieve the purpose of the human development index properly. This is in line with the poverty circle theory which states that when the absence of a balanced development then the HDI itself not going well.

3. The effect of unemployment on HDI

Based on the results of multiple linear regression on the regression coefficient, it is obtained a positive value of -0.299380 and prob. $0.6655>0.05$. Then it is concluded that the unemployment variable has a negative but not relevant effect on the human development index. (H3 rejected).

Unemployment itself has many types, one of which is unemployment seasonality, where the unemployed are unemployed in the long run certain time. So, when a person works, the income is will still suffice when the person is not working. This explains that the increase in unemployment is not always followed by the HDI level also increases.

4. Effect of per capita income on HDI

Based on the results of multiple linear regression on the regression coefficient obtained a positive value of 0.026978 and prob. $0.3841>0.05$. Then it is concluded that the income per capita variable has a positive but not relevant effect on the human development index. (H4 rejected)

Income per capita of the people in Central Java districts/cities have not been able to increase HDI in the area caused by the relatively small income which is owned. This condition results in the allocation of consumption greater primary needs, so that expenditures for the education and health sectors are relatively limited which makes HDI quality is less noticed and neglected.

5. The effect of zakat on economic growth

It is shown that the regression coefficient value is 0.021442 with prob. $0.0000<0.05$. Then it is concluded that the zakat variable has a positive and relevant effect on economic growth. (H5 accepted)

The hypothesis in this study states that the better distribution of zakat funds, the better the effect on economic growth. Zakat both consumptively and productive can encourage people to carry out activities economy so that it can move the economy well with the assumption that the distribution of zakat funds can well and evenly distributed.

6. The effect of poverty on economic growth

It is shown that the regression coefficient value is -0.119146 and prob. $0.0000<0.05$. Then it is concluded that the poverty variable has a negative and relevant effect on economic growth. (H6 accepted)

This explains that the higher the poverty rate, the economic growth is declining. This is because the occurrence of inequality in the welfare of society which impact on economic growth with the crisis the economy.

7. The effect of unemployment on economic growth 


\section{$A \mathrm{C} \overline{I E B}$ Annual International Conference \\ on Islamic Economics and Business, 2021}

It is shown that the regression coefficient value is negative worth -0.018770 and the prob value. $0.7060>0.05$. Then it is concluded that the unemployment variable has a negative but not relevant effect on economic growth. (H7 rejected)

In Central Java alone many manufacturing companies or factories. Well, company in absorbing labor, of course, does not absorb overall, of course adjusting to the needs during still meet the factors of production which in the end still can optimally produce the product. So, when unemployment increase or decrease will not affect economic growth.

8. The effect of per capita income on economic growth

It is stated that the regression coefficient value is negative as much as 0.002123 and the prob value. $0.3382>0.05$. Then it is concluded that the income per capita variable has a positive but not relevant effect on economic growth. (H8 rejected)

This explains when per capita income increases not always followed by increased economic growth either. An increase in per capita income may not increase the real standard of living of the population, the per capita income may be high but per capita consumption is declining, people can choose use their income to increase savings, or the government spends its revenue on military purposes or other needs.

9. Effect of economic growth on HDI

It is shown that the regression coefficient value is positive as much as 4.210373 and the probability value is $0.0087<0.05$. Then it is concluded that the variable of economic growth has a positive and relevant effect on HDI. (H9 accepted)

With an increase in productivity will increase opportunities employment so that the labor market can develop. When If someone has a job then the need will be fulfilled, with the fulfillment of needs means the quality of life of the community can be encouraged so that the welfare of society will increase.

10. The effect of zakat on HDI with economic growth as a mediating factor

Based on the results of the Sobel test, the t-count value is $0.036<\mathrm{t}$-table worth 1.65857 . Then it is stated that zakat has no effect on HDI which is mediated by economic growth. (H10 rejected)

Basically, zakat is used as capital for develop HDI. But in the development of HDI not only supported by the presence of capital. In fact, with capital but human resources are low then welfare is not maximally exceeded. Different when there is no capital however good human resources, one can hone skills with the skills they have. So, the development index humans can be channeled well. Means a good HDI is not always determined by the existence of capital, but more to the HR itself in supporting economic growth. In this case it is possible that there are other factors that can mediate zakat on human development index.

11. The effect of poverty on the human development index through economic growth as a mediating variable

Based on the results of the Sobel test, the t-count value is 0.207 , which is smaller than the $\mathrm{t}$-table, which is 1.65857 . Then it is stated that poverty has no effect on HDI which is mediated by economic growth. (H11 rejected)

Poverty There are some that are permanent and temporary. Fixed when someone doesn't want to try and they will still choose be poor. This is classified as cultural poverty. Then poverty is temporary due to many factors, for example during a pandemic, there is a time when the economy is hampered, but in fact it does not drag on pandemic, one can still rise when the pandemic is over. Factor others, such as the agricultural sector, which yields good yields or not good. Then from the natural disaster factor. So, In this case, temporary poverty does not affect the HDI in supporting economic growth.

12. The effect of unemployment on HDI with economic growth as a mediating factor 


\section{$A \bar{C} \overline{I E B}$ Annual International Conference \\ on Islamic Economics and Business, 2021}

Based on the results of the Sobel test, the t-count value is 0.217 which is smaller than the $\mathrm{t}$-table, which is 1.65857. Then it is stated that unemployment has no effect on HDI which is mediated by economic growth. (H12 rejected)

This explains that there are other possible factors that could mediate the effect of unemployment on the development index man. There are temporary/seasonal unemployment, where a person can still meet their needs when that person is not working. This can also be shown by those who not working but can still be productive. So, when unemployment increase or decrease does not affect the development index and remain stable in supporting economic growth.

13. The effect of per capita income on HDI with economic growth as a mediating factor Based on the results of the Sobel test, the t-count value is $0.009<\mathrm{t}$-table worth 1.65857. Then it is stated that per capita income has no effect on the human development index mediated by economic growth. (H13 rejected)

In this case because there is a possibility when high per capita income but poverty occurs increasing because income only flows in only the rich. Other factors such as inequality in the distribution of goods and services so that there is no can be distributed evenly. So that the hypothesis states the higher or lower the income per capita, the HDI remain stable. There may be other factors that can mediate income per capita on the human development index

\section{References}

BPS. (2020). No Title. Central Bureau of Statistics. https://www.bps.go.id/pressrelease/2020/12/15/1758/index-development-human--ipm-indonesia-pada-tahun-2020-menreach-71-94.html

Juliarini, A. (2019). Regional Revenue Performance Against Human Development Index Case Study Province in Java Island. Journal of Good Governance, 15(1), 934-957. https://doi.org/10.32834/gg.v15i1.99

Murniati, R., \& Beik, I. S. (2012). The Effect of Zakat on Human Development Index and Poverty Level Mustahik: A Case Study of the Utilization of BAZNAS in Bogor City. Journal of Al-Muzara'ah, 2(2), 135-149. https://media.neliti.com/media/publications/261326-unjuk-zakat-terhadap-indexpembangun-452306bd.pdf

Ningrum, J. W., Khairunnisa, A. H., \& Huda, N. (2020). The Effect of Poverty, Unemployment Rate, Economic Growth and Government Expenditure on the Human Development Index (HDI) in Indonesia 2014-2018 in an Islamic Perspective. Scientific Journal of Islamic Economics, 6(2), 212. https://doi.org/10.29040/jiei.v6i2.1034

Riadi, L. (2020). The Effect of Zakat, Infaq and Shodaqoh (ZIS) of the Amil Zakat Institute in Sidogiri Bangkalan on the Mustahik Human Development Index (IPM). Journal of Tanwirul Uqul, 1(2), 1-144.

Sasana, H. (2012). The Influence of Local Government Expenditures and Per Capita Income on the Human Development Index. Journal of Media Economics and Management, 25(1), $1-12$.

Suparyati, A. (2014). Effect of Economic Freedom and Income. Journal of Media Economics, 22(2), 171-182.

Syukri, S., \& Gunawan, E. (2020). Analysis of the Effect of Zakat on the Human Development Index (IPM) Mustahik (Case Study: Baitul Mal, Banda Aceh City). Scientific Journal of Economics Students, 1, 80-97. http://www.jim.unsyiah.ac.id/EKI/article/view/16243 